\title{
Pelaksanaan Pemberian Tugas Bisa Meningkatkan Kemampuan pada Anak TK Negeri Pembina Sungai Raya dalam Mengenal Warna
}

\author{
Usnah \\ Kepala Sekolah TK Negeri Pembina Sungai Raya Kalimantan Barat \\ Email: usnahpontianak@gmail.com
}

Abstract. The implementation of giving assignments can improve the ability of tk negeri pembina raya children to recognize colors. The ability to recognize colors in children 5-6 years in terms of designating, mentioning, and grouping colors is still lacking. Therefore, we need the right method to improve children's ability to recognize colors. The purpose of this study was to describe the implementation of this assignment to improve the ability of the children of Group B of the Pembina Raya Kindergarten in recognizing colors. The method used in this research is classroom action research (PTK). The research subjects were children of Group B of the Pembina Raya Kindergarten, using data collection tools in the form of observation and assignments. From the results of the given assignments, it was found that the child's ability to recognize colors (pointing, mentioning, and grouping) after being accumulated in cycle I was $31.11 \%$, and cycle II there was $82.22 \%$. This shows an increase in the child's ability to recognize colors on the given task. Thus, the implementation of assigning assignments to Group B Kindergarten Children of Raya Sungai Raya, Kubu Raya Regency in the ability to recognize colors increases.

Keywords: Improve; Identify colors; Assign assignments

\begin{abstract}
Abstrak. Pelaksanaan Pemberian Tugas Bisa Meningkatkan Kemampuan pada Anak TK Negeri Pembina Sungai Raya dalam Mengenal Warna. Kemampuan mengenal warna pada anak 5-6 tahun dalam perihal menunjuk, menyebutkan, serta mengelompokkan warna masih kurang. Oleh karena itulah, diperlukan metode yang tepat untuk meningkatkan kemampuan anak dalam mengenal warna. Tujuan penelitian ini adalah mendeskripsikan pelaksanaan pemberian tugas ini meningkatkan kemampuan pada anak kelompok B Taman Kanak-kanak Negeri Pembina Sungai Raya dalam mengenal warna. Metode yang digunakan pada penelitian adalah penelitian tindakankelas (PTK). Subjek riset merupakan anak kelompok B Taman Kanak-kanak Negeri Pembina Sungai Raya dengan menggunakan alat pengumpulan data berupa observasi dan pemberian tugas. Dari hasil tugas yang diberikan diperoleh kemampuan anak mengenal warna (menunjuk, menyebutkan, dan mengelompokkan) setelah diakumulasikan pada siklus I terdapat $31,11 \%$, dan siklus II terdapat $82,22 \%$. Hal ini menunjukkan adanya peningkatan kemampuan anak mengenal warna pada tugas yang diberikan. Dengan demikian, pelaksanaan pemberian tugas pada anak Kelompok B Taman Kanak-kanak Negeri Pembina Sungai Raya Kabupaten Kubu Raya dalam kemampuan mengenal warna meningkat.
\end{abstract}

Kata kunci : Meningkatkan; Mengenal warna; Pemberian tugas. 


\section{PENDAHULUAN}

Aktivitas

pengembangan pendidikan ialah sesuatu aplikasi salah satu aktivitas pengembangan bersumber pada pendekatan kurikulum terpadu yang bertujuan buat menghasilkan ataupun membuat proses pendidikan secara relavan serta bermakna untuk anak (Baniyah, 2009). Di antara uraian kalau pertumbuhan secara ilmiah terjalin sesuatu perihal pada pendidikan semacam pertumbuhan raga, tidak bisa dipungkiri senantiasa pengaruhi pertumbuhan aspek pertumbuhan yang lain, sepeti pertumbuhan social serta emosional perkembangan aspek perkembangan lainnya, seperti perkembangan social dan emosional (Susanto, 2012). Pembagian pembelajaran yang disesuaikan dengan bidang studi tertentu didalam kurikulum akan berimplikasi dalam pembelajaran karena anak akan memperoleh pemahaman melalui suatu yang terpisahpisah.

Hal ini bertentangan dengan cara anak dalam belajar. Anak akan mengaitkan antara pengalaman dan gagasannya dengan keterampilan belajar yang dibutuhkan untuk digunakan dalam konteks yang bermakna dan menarik baginya (Yuliani, 2009). Oleh karena itu, sangat diperlukan dalam proses, pengembangan kemampuan dasar dan perilaku anak.

Dalam beberapa aktifitasnya (Desmita, 2009) mencakup beberapa aspek pertumbuhan yang berkaitan dengan bidang riset, semacam sains, matematika, pengetahuan social, serta bahasa. Kurikulum pendidikan pula membolehkan anak buat membangun ikatan mental yang bermakna tanpa pembelahan yang terencana (Anggani, 2000). Tidak hanya itu, kurikulum ini membolehkan anak memfungsikan segala aspek pengembangannya dalam menggapai sesuatu topic ataupun atensi
DOI:

memakai pengetahuan serta keahlian yang dicapai lewat kontek yang bermakna.

Dengan pengalaman-pengalaman baru yang telah diperoleh, telah terjadi perubahan-perubahan membimbing anak disekolah, karena sudah selayaknya guru dituntut untuk meningkatkan hasil dan prestasi belajar yang kurang atau yang mendapat masalah, oleh karena itu banyak anak-anak yang berprestasi dalam belajar mengajar karena guru mengajarkan tanpa menggunakan metode atau model dan perencanaan yang dijadikan sebuah pedoman (Winda, 2008).

Dalam kegiatan pembelajaran di Taman Kanak-kanak Negeri Pembina Sungai Raya Kabupaten Kubu Raya, saat berada dikelas sering kali peneliti mengajar menggunakan metode pembelajaran yang berpusat hanya kepada guru sebagai pembimbing, pembelajaran seperti ini selalu membuat anak menjadi bosan dengan materi yang disampaikan oleh guru kurang diminati oleh anak dan selalu mencari pencapaian kemampuan membedakan warna yang berhubungan langsung dengan kertas biasa. Dalam menghadapi masalah rumit yang dipecahkan bersama teman-teman guru. Peneliti berasumsi bahwa ada beberapa kelemahan yang mendasari bagian rutinitas yang biasa dilakukan. Adapun permasalahan yang ditemui dilapangan adalah anak-anak kurang memperhatikan apabila diberi pertanyaan dari guru, pada tahap kegiatan menggambar beberapa anak menunjukkan kurangnya kemampuan membedakan warna dalam pembelajaran tertentu. Pada kegiatan bernyanyi ini semua anak dengan sendirinya, dan anak kurang memberikan tanggapan terhadap pelajaran.

Anak-anak diberi sebuah gambaran warna yang dianggap membawa anak kepada kemandirian belajar mencari 
warna, ini pun menjadi pancingan untuk anak aktif dalam metode pemberian tugas yang akan dilaksanakan nantinya dalam penelitian ini (Nugraha, 2008).

Dari pengalaman belajar yang telah dipaparkan diatas, terlihat banyak kendala yang dihadapi oleh peneliti seperti anak-anak yang kurang memperhatikan apabila diberi pertanyaan dari guru dan pada tahap kegiatan menggambar beberapa anak menunjukkan kurangnya keamampuan membedakan warna dalam pelajaran tertentu (Tedja, 2001). Dengan adanya pengalaman telah lalu, guru melihat adanya anak yang mempunyai masalah pada tahap kegiatan menggambar beberapa anak menunjukkan kurangnya kemampuan membedakan warna (Haryono, 2007).

Keahlian memahami warna pada anak umur 5- 6 tahun dalam perihal menunjuk, menyebut, serta mengelompokkan warna masih kurang. Pada dikala proses pemelajaran di Halaman Anak- anak Negara Pembina Sungai Raya Kabupaten Kubu Raya tahun pelajaran 2019/2020, ada 21\% saja kanak- kanak sanggup dalam membedakan warna. Guru memohon kanak- kanak menunjuk warna kuning, anak masih menampilkan 2 warna yang berbeda ialah kuning serta orange. Keahlian anak dalam mengatakan warna, yang sepatutnya merupakan warna orange diucap warna merah, begitu kebalikannya yang sepatutnya warna merah diucap warna orange. Sebagian anak dalam mengelompokkan warna merah masih belum pas, yang sepatutnya mengelompokkan 3 warna merah, sebab tidak seluruh warna sama. Perihal tersebut menampilkan kalau keahlian anak buat menunjuk, mengatakan, serta mengelompokkan warna masih lemah. Pada sesi kedua ialah pra- operasional, dimana sesi ini pokok pertumbuhan merupakan memakai symbol serta bahasa ciri.

Bagian-bagian permasalahan yang telah disampaikan, kemudian pada permasalahan-permasalahan tersebut, guru sebagai peneliti harus mencari solusi pengembangan metode pembelajaran dalam mengajar bimbingan belajar. Salah satu metode atau model pembelajaran pemberian tugas yang dimungkinkan akan mampu mengatasi permasalahan seperti anak-anak yang kurang mampu memperhatikan apabila diberi pertanyaan. Kegiatan pemberian tugas sangat pas digunakan dalam menghadirkan warna sebab sangat menarik buat anak serta cocok dengan perkembangannya. Tata cara pemberian tugas merupakan tata cara yang membagikan peluang pada anak melakukan tugas bersumber pada petunjuk langsung dari guru apa yang wajib dicoba serta dikerjakan, sehingga anak bisa menguasai tugasnya secara nyata serta dilaksanakan secara tuntas (Sujiono, 2008).

Berdasarkan permasalahan yang dihadapi, diperlukan metode yang tepat untuk meningkatkan kemampuan anak dalam mengenal warna (Porter \& Hemacki, 2000). Dengan pelaksanaan pemberian tugas pada anak kelompok B Taman Kanak-kanak Negeri Pembina Sungai Raya Kabupaten Kubu Raya diharapkan dapat meningkatkan kemampuan anak dalam mengenal warna.

Metode pemberian tugas dapat diberikan secara kelompok dan perorangan. Yang harus diperhatikan dalam pemberian tugas adalah kejelasan tugas yang harus dilaksanakan dan pembatasan pemberian tugas (Montolalu, 2005). Pemberian batasan tugas harus dilaksanakan dan pembatasan pemberian tugas. Pemberian batasan tugas merupakan syarat mutlak pada metode ini dan menjadi perhatian guru Taman 
Kanak-kanak atau peneliti. Seringkali anak mengalami hambatan untuk memperoleh kemajuan belajar karena tidak menentukan batasan yang harus dikerjakannya. Hal ini yang harus jadi perhatian adalah penjelasan guru kepada anak, mengapa mereka harus mengerjakan tugas tersebut. Sehingga tugas yang diberikan jelas.

Warna adalah unsur pertama yang terlihat oleh mata dari suatu benda (Depdiknas, 2009). Mengenalkan warna kepada anak dapat membentuk struktur kognitif, dalam proses pembelajaran sehingga anak akan memperoleh informasi yang lebih banyak dan menjadikan pembelajaran menjadi lebih bermakna. Menurut (Soewignjo, 2013) penafsiran warna bisa dibedakan jadi 2 ialah secara subyektif (secara psikologis) serta secara obyektif (secara raga). Secara subyektif warna dimaksud selaku bagian dari pengalaman indera penglihatan. Sebaliknya secara obyektif warna dimaksud selaku hasil dari panjang gelombang sinar yang dipancarkan. Bagi (Musfiroh, 2008) cipta warna ialah aktivitas bermain dengan perona, baik dalam wujud kertas krep, perona santapan, ataupun finger painting yang bertujuan memicu kepekaan warna (Mutiah, 2010). Cipta warna terbuat dengan menggabungkan 2 warna sampai membentuk warna baru. Perihal ini cocok dengan komentar (Rasyid, 2009) kalau menyebut, mengklasifikasikan, membedakan, serta menghitung warna ialah keahlian kognitif-logika anak yang digunakan selaku dasar melaksanakan asimilasi, menyesuaikan diri, serta akomodasi terhadap area serta suasana baru (Depdiknas, 2007). bagi periset warna ialah kesan yang diperoleh mata dari sinar yang mempunyai faktor keelokan dari sesuatu barang yang bisa dibedakan (Soewignjo, 2013). Keahlian memahami warna pada anak ialah faktor berarti yang bisa menolong anak dalam memahami unsur- unsur keelokan yang berwujud serta bisa dinikmati oleh indra penglihatan cocok dari wujud ruang (warna) tersebut. Secraa etimologi keahlian dimaksud selaku kesanggupan ataupun kecakapan. Keahlian merupakan kapasitas orang melakukan bermacam tugas dalam sesuatu pekerjaan (Abdullah \& Suratno, 2015). Berdasakan komentar tersebut, hingga kemmapuan memahami warna bagi periset merupakan kesanggupan anak dalam dalam mengenali warna dengan metode menunjuk, menyebut, serta mengelompokkan warna yang dimaksudkan guru lewat kegiatankegiatan pengenalan warna.

Lewat kegiatan- kegiatan tersebut diharapkan membagikan pengalaman riil ataupun nyata kepada anak sebab mereka bisa memandang, merasakan, serta meraba dikala aplikasi langsung dalam kegiatan- kegiatan tersebut. Anak memperoleh pengalaman- pengalam langsung dari aktivitas tersebut.

\section{METODE}

Subjek riset ini merupakan Anak Umur Dini Kelompok B Halaman Anakanak Negara Sungai Raya Kabupaten Kubu Raya tahun pelajaran 2019/ 2020, yang berjumlah 15 anak dengan anak pria 6 orang serta anak wanita 9 orang. Objek riset merupakan kenaikan keahlian anak dalam memahami warna lewat pemberian tugas. Riset ini menggunkan metode non uji (Arikunto, 2006, p. 4). Tata cara ini digunakan dengan dorongan alat- alat non uji (Burhan, 2006, p. 43). Serta perlengkapan evaluasi non uji yang digunakan merupakan pemberian tugas serta observasi.

Penelitian ini dilaksanakan pada tanggal 14 s/d 21 Oktober 2019 di Taman Kanak-kanak Negeri Pembina Sungai Raya, Jalan Adi Sucipto Km 12,5 Sungai Raya Kabupaten Kubu Raya (Acep, 2010). Adapun metode yang digunakan 
pada penelitian ini adalah penelitian tindakan kelas (PTK). Penelitian tindakan kelas (PTK) pada penelitian ini dilaksanakan sebanyak dua siklus yaitu siklus I dan siklus II. Pada penelitian ini jika siklus I tidak tercapai, yaitu proses belajar mengajar tidak berjalan dengan baik sehingga aktivitas anak masih rendah maka dilaksanakan siklus II dikelas yang sama dalam waktu yang berbeda, untuk mencapai hasil yang diinginkan.

Pada awal penelitian dilakukan penelitian pratindakan yang diperoleh melalui pengamatan langsung dalam kelas. Untuk mengetahui permasalahan dilakukan observasi langsung didalam kelas dan memberikan kegiatan sesuai materi dan permasalahan. Pengamatan atau observasi yang dilakukan bertujuan untuk mengetahui kemampuan awal anak, dimana hasil observasi ini dijadikan acuan untuk menentukan media yang menarik bagi anak. Hasil dari pengamatan langsung atau observasi awal ini kemudian digunakan sebagai dasar untuk melaksakan kegiatan pembelajaran pada siklus I. tahap pertama yaitu tahap perencanaan I. Pada tahap ini peneliti membuat rencana pembelajaran (RPPH), menyiapkan kertas origami, menyiapkan lembar penugasan anak, membuat lembar observasi, membuat format lembar penugasan anak untuk mengetahui kemampuan pengenalan warna. Tahap selanjutnya yang dilakukan pada siklusI adalah pelaksanaan tindakan I. Pada tahap ini peneliti membagi anak menjadi 3 kelompok, masing-masing kelompok diberikan tugas dapat menunjuk, menyebut, dan mengelompokkan warna dari kertas origami yang diberikan. Pada tahap pengembangan (Inti) guru menyiapkan kertas origami warna-warni (biru, orange, pink/merah muda) yang dipotong berbentuk segi empat dengan ukuran 10x10, guru menyiapkan kertas, lem untuk menempel, guru mendemontrasikan origami warna-warni, guru meminta kepada anak-anak untuk menyebutkan warna origami yang dipegang oleh guru, guru membimbing anak yang belum bisa menunjukkan warna dan menyebutkan warna. Guru membagikan kertas yang telah digaris berbentuk kotak sebanyak tiga buah kotak dan ditengah-tengah kotak terdapat potongan kertas origami dengan warna biru, orange, pink/merah muda. Guru memberikan contoh untuk mengelompokkan warna dengan potongan kertas origami, kelompok biru dalam kotak biru, orange dengan kotak orange, dan pink (merah muda) dengan kotak pink (merah muda), kemudian ditempel. Guru memberikan tugas pada anak untuk mengelompokkan warna sama seperti yang dicontohkan guru. Guru melakukan penilaian terhadap kegiatan anak.

Pada akhir tindakan I ini siswa diberikan penugasan tentang kemampuan pengenalan warna untuk melihat sejauh mana kemampuan anak. Tahap berikutnya pada siklus I adalah observasi dan penilaian, pada tahap ini observasi dilakukan bersamaan dengan tahap pelaksanaan tindakan I, yaitu saat kegiatan proses pembelajaran berlangsung. Observasi ini bertujuan untuk melihat aktifitas belajar anak. Peneliti bertindak sebagai observer dan dibantu oleh seorang guru. Lembar penilaian dilaksanakan setelah kegiatan dalam pengenalan warna dilakukan. Kemudian dilanjutkan pada tahap analisis data I, pada tahap ini data yang diperoleh dari kegiatan belajar mengajar dengan tujuan indikator kemmapuan mengenal warna, data hasil observasi kemudian dianalisis melalui 3 tahap yaitu reduksi data, paparan data, dan menarik kesimpulan. Reduksi data yang diperoleh dari hasil wawancara guru, observasi, dan catatan dari awal hingga penelitian 
selesai. Kemudian pada tahap ini setelah reduksi data dilakukan paparan data berupa tabel, gambar / skema yang diperoleh dari reduksi data, dan yang terakhir yaitu menarik kesimpulan. Tahap terakhir pada penelitian ini yaitu Refleksi, pada tahap ini kesimpulan dari analisis kemudian dijadikan refleksi untuk melihat ketuntasan belajar,aktifitas belajar dan kemampuan pengenalan warna. Selain itu, peneliti dan guru sebagai partner melakukan evaluasi terhadap proses pembelajaran yang telah dilaksanakan, permasalahan apa saja yang diperoleh selama pembelajaran sehingga dapat disusun rencana pada siklus selanjutnya. Hasil refleksi ini kemudian digunakan sebagai dasar untuk tahap perencanaan pada siklus II.

Siklus II dilaksanakan dikelas yang sama dengan siklus I, dalam waktu yang berbeda. Tahap-tahap penelitian pada siklus II sama dengan siklus I, hanya saja pada pelaksanaan tindakan II pembelajaran dilakukan berdasarkan hasil penelitian. Pada tahapan perencanaan pada siklus II ini adalah menyusun perangkat pembelajaran, yang meliputi rencana pembelajaran harian, dengan materi tema tanaman subtema tanaman hias. Kemudian menyiapkan alat/media dari potongan kertas origami, menyiapkan lembar pengamatan dan penilaian anak. Tahap selanjutnya yaitu tahap pelaksanaan. Pertemuan pada siklus II ini dilaksanakan pada hari senin, 21 Oktober 2019 dalam pelaksanaan guru menggunakan metode observasi, percakapan, penugasan dan menggunakan media yang sama pada siklus I yaitu potongan-potongan origami warna-warni, kertas, lem. Pada kegiatan pengembangan II (Inti), guru menyiapkan media pembelajaran berupa potongan kertas origami warna-warni. Kertas dan lem. Kemudian guru memperlihatkan kertas origami warna-warni kepada anak, kemudian guru meminta kepada anak untuk menyebutkan warna-warna yang dilihatkan guru secara bersama-sama, guru memberikan kesempatan kepada anak untuk menyebutkan warna kertas origami satu persatu dan meminta mereka untuk menunjukkan warna yang disebut. Selanjutnya, guru memberikan bimbingan pada anak yang tidak bias menyebutkan warna-warna, guru memberikan pujian terhadap anak yang dapat menunjukkan dan menyebutkan warna-warna kertas origami. Setelah kegiatan menyebut dan menunjuk kertas origami warna-warni, anak diberi penugasan untuk mengelompokkan warna berdasarkan warna. Guru membagikan kertas dimana terdapat tiga buah bentuk segitiga tengahnya, terdapat potongan kertas origami warna terdiri dari tiga warna kuning, merah, dan hijau. Guru memberikan penjelasan tentang tugas yang dikerjakan, yaitu mengelompokkan warna berdasarkan warna, origami warna hijau dalam bentuk segitiga maka potongan origami yang berwarna hijau akan ditempel pada bentuk segitiga yang mempunyai warna hijau. Bentuk segitiga yang terdapat warna merah maka potongan warna merahakan ditempel pada bentuk segitiga warna merah. Begitu pula dengan bentuk segitiga yang mempunyai warna kuning akan ditempel pada segitiga warna hijau. Kemudian guru memberikan kesempatan kepada anak untuk bertanya dan mengemukakan pendapat mengenai tugas yang diberikan. Kemudian, guru memberikan potongan origami dan lem, guru mengamati tugas yang diberikan, guru membimbing pada anak yang kurang mampu dalam melaksanakan tugas, dan guru memberikan penilaian kepada anak setelah tugas selesai dikerjakan. Pada kegiatan akhir pembelajaran (penutup) ini, kegiatan mengulas kembali tentang kegiatan yang telah dilakukan, bercerita tentang tanaman hias, menyampaikan pesan- 
pesan dan menyampaikan informasi tentang kegiatan-kegiatan esok harinya. Diharapkan pada kegiatan akhir inianak dapat mendapat kegembiraan dalam melaksanakan kegiatan sehingga anak senang untuk bersekolah dan senang dating kesekolah, tidak merasa takut, tidak cemas, tidak murung, bahkan tidak mudah marah.

Tahap selanjutnya pada siklus II ini adalah tahap observasi dan penilaian. Observasi dan penilaian dilaksanakan pada saat kegiatan belajar mengajar berlangsung. Kegiatan yang diamati adalah kegiatan waktu tanya jawab,dan pemberian tugas dalam mengelompokkan kertas origami. Guru dapat memberikan penilaian yang objektif berdasarkan kejadian yang telah terjadi. Dalam penilaian kegiatan mengelompokkan warna, guru menggunakan instrument / format penugasan anak. Setiap anak maka akan mendapat satu format penugasan anak. Tahap terakhir pada siklus II ini adalah tahap refleksi. Setelah melaksanakan kegiatan pembelajaran pada siklus II dari pertemuan pertama dan kedua,maka selanjutnya diadakan refleksi dalam bentuk diskusi atas segala kegiatan dalam proses pembelajaran. Dalam diskusi yang berisi tentang: upaya meningkatkan kemampuan pengenalan warna dengan metode pemberian tugas pada kelompok $\mathrm{B}$, anak menjadi aktif dalam belajar, tujuan pembelajaran tercapai, dapat memberikan kesempatan pada anak untuk bertanya jawab, anak focus pada penjelasan yang diberikan guru sehingga kegiatan belajar mengajar efektif. Namun meskipun demikian masih tetap diperlukan perbaikan secara berkesinambungan agar hasil belajar yang sudah dimulai meningkat lebih dapat berkembang dan dapat ditingkatkan menjadi lebih baik lagi.

\section{HASIL DAN PEMBAHASAN}

\section{Hasil}

Hasil penelitian ini yang diperoleh yang dimulai dari pratindakan, siklus I, dan siklus II pada kemampuan anak kelompok B Taman Kanak-Kanak Negeri Pembina Sungai Raya Kabupaten Kubu Raya tahun pelajaran 2019/2020 dalam mengenal warna dapat digambarkan sebagai berikut :

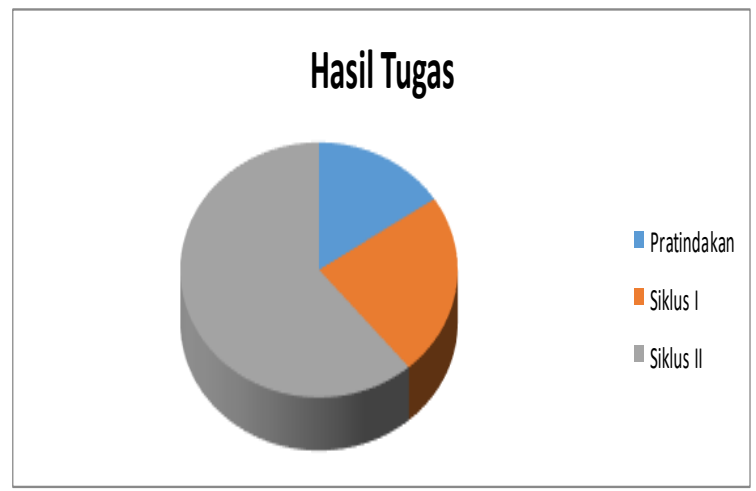

Gambar.1 Kemampuan Mengenal Warna

Pada gambar.1 dapat dipaparkan bahwa hasil kemampuan anak kelompok B Taman Kanak-Kanak Negeri Pembina Sungai Raya Kabupaten Kubu Raya tahun pelajaran 2019/2020 dalam mengenal warna dengan baik diperoleh data $21 \%$ pada saat pratindakan, $31,11 \%$ pada saat siklus I, dan $82,22 \%$ pada saat siklus II.

\section{Pembahasan}

Pada penelitian ini pengenalan warna ialah salah satu penanda sains tercantum ke dalam bidang pengembangan kognitif (Rosalina \& Nurhenti, 2019). Mengenalkan warna kepada anak bisa membentuk struktur kognitif, dalam proses pendidikan anak hendak mendapatkan data yang lebih banyak sehingga pengetahuan serta pemahamannya hendak lebih kaya serta lebih dalam. Dalam perihal ini anak mengenali warna secara konsep bersumber pada pengalaman belajarnya. 
Berdasarkan data hasil tugas dalam bentuk persentase kemampuan mengenal warna pada anak kelompok B Taman Kanak-kanak Negari Pembina Sungai Raya tahun pelajaran 2019/2020 sebagai berikut:

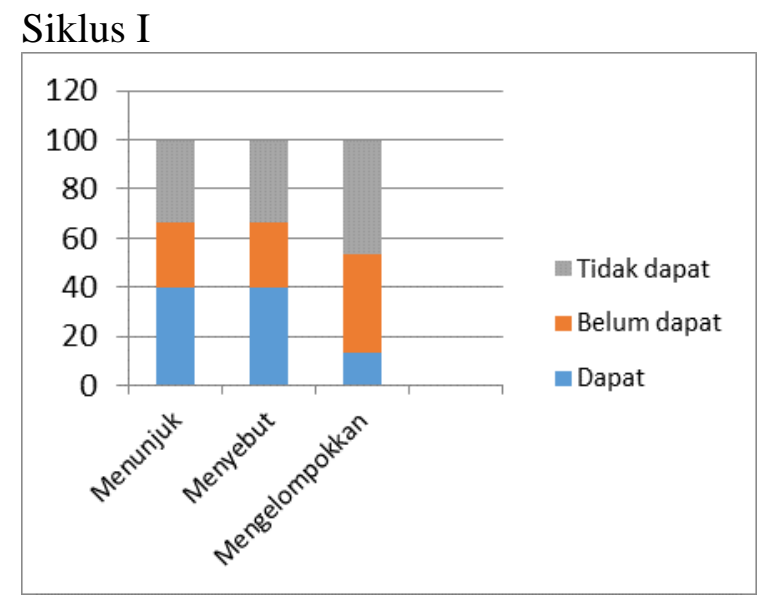

Gambar 2. Kemampuan Mengenal Warna

Data pada gambar 2 diperoleh dari hasil tugas yang diberikan kepada 15 orang anak. Kemampuan mengenal warna Pada dinilai bagi 3 (tiga) keahlian ialah menunjuk, menyebut, serta mengelompokkan. Pada gambar.1 dapat dipaparkan bahwa pada siklus I dengan katagori pertama yaitu menunjuk, hanya 6 orang anak (40\%) dapat menunjuk warna dengan baik, 4 orang anak $(26,67 \%)$ belum dapat menunjuk warna, dan 5 orang anak $(33,33 \%)$ tidak dapat menunjuk warna. Pada kategori kedua yaitu menyebut, hanya 6 orang anak (40\%) dapat menyebut warna dengan baik, 4 orang anak $(26,67 \%)$ belum dapat menyebut warna, dan 5 orang anak $(33,33 \%)$ tidak dapat menyebut warna. Pada kategori ketiga yaitu mengelompokkan, 2 orang anak $(13,33 \%)$ dapat mengelompokkan warna dengan baik, 6 orang anak (40\%) belum dapat mengelompokkan warna, dan 7 orang anak $(46,67 \%)$ tidak dapat mengelompokkan warna. Hasil akumulasi pada siklus I ini kemampuan anak dengan jumlah 15 orang dalam mengenal warna pada anak kelompok B Taman Kanak-kanak Negeri Pembina Sungai Raya adalah dengan kategori baik $31,11 \%$ dapat mempelajari warna dengan baik, dan kategori cukup $31,11 \%$ belum dapat mempelajari warna dengan baik, serta $37,77 \%$ tidak dapat mengenal warna dengan baik. Berdasarkan hasil analisis pengolahan data yang diperoleh, hasil diskusi dari guru dan peneliti dapat diketahui bahwa pembelajaran yang dilakukan pada siklus I belum menunjukkan keberhasilan. Hal ini disebabkan kurang efektifnya penggunaan waktu, serta kurangnya ketertarikan anak dalam melaksanakan tugas yang diberikan, serta memotivasi dan pujian yang kurang dapat membuat anak kurang percaya diri.

\section{Siklus II}

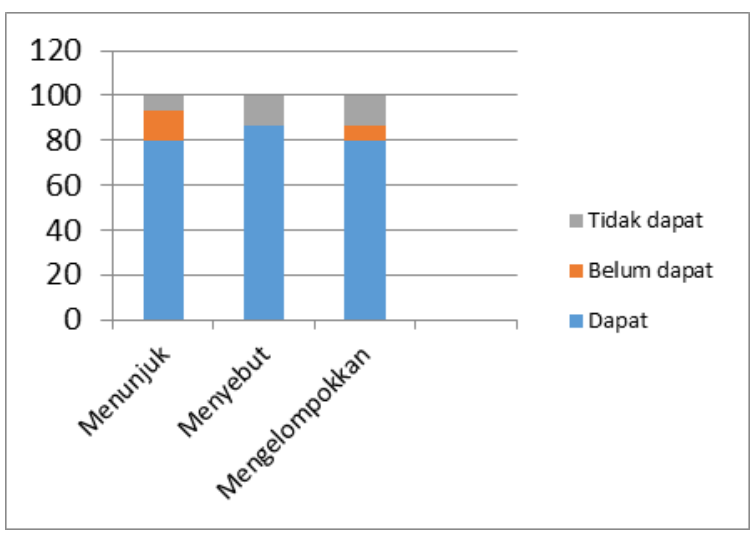

Gambar 3. Kemampuan Mengenal Warna

Pada siklus II gambar 3 dapat dipaparkan hasil kemampuan anak kelompok B Taman Kanak-kanak Negeri Pembina Sungai Raya. Pada katagori pertama yaitu menunjuk, hanya 12 orang anak (80\%) dapat menunjuk warna dengan baik, 2 orang anak (13,33\%) belum dapat menunjuk warna, dan 1 orang anak $(6,67 \%)$ tidak dapat menunjuk warna. Pada kategori kedua yaitu menyebut, hanya 13 orang siswa $(86,67 \%)$ dapat menyebut warna dengan baik, dan 2 orang anak (13,33\%) tidak 
dapat menyebut warna. Pada kategori ketiga yaitu mengelompokkan, 12 orang anak $(80 \%)$ dapat mengelompokkan warna dengan baik1 orang anak $(6,67 \%)$ belum dapat mengelompokkan warna, dan 2 orang anak $(13,33 \%)$ tidak dapat mengelompokkan warna. Hasil akumulasi pada siklus II ini kemampuan anak dengan jumlah 15 orang dalam mengenal warna pada anak kelompok B Taman Kanak-kanak Negeri Pembina Sungai Raya adalah dengan kategori baik $82,22 \%$ dapat mengenal warna dengan baik, dengan kategori cukup 6,67\% belum dapat mengenal warna dengan baik, dan $11,11 \%$ tidak dapat mengenal warna dengan baik.

Dari hasil pelaksanaan pemberian tugas pada anak kelompok B Taman Kanak-kanak Negeri Pembina Sungai Raya tahun pelajaran 2019/2020 dalam kemampuan mengenal warna terdapat peningkatan. Hal ini dapat dilihat dari hasil data yang diperoleh pada siklus I dan siklus II yang telah dipaparkan.

Keadaan prestasi belajar anak pada siklus II sudah menunjukkan peningkatan yang baik. Adanya peningkatan dan minat belajar anak maka tujuan pembelajaran akan mudah tercapai. Sehingga kegiatan pembelajaran pada siklus II sudah mencapai ketuntasan. Dalam kemampuan pengenalan warna, anak sudah dapat menyebutkan warna, menunjukkan warna, dan mengelompokkan warna.

Pada riset yang sudah dilaksanakan proses pendidikan pengenalan warna mengacu pada pendidikan yang sistematis, sebab dalam evaluasi hasil pendidikan bisa terukur serta teramati. Anak bisa menunjuk maksudnya anak sanggup memperlihatkan warna dengan metode mengacungkan ataupun memusatkan warna dengan jarinya, keahlian tersebut bisa tercipta lewat penugasan bahasa serta motorik halus anak dengan terhadap warna. Anak bisa mengatakan maksudnya anak sanggup mengucapkan ataupun melaporkan warna yang dilihat dengan benar, keahlian tersebut bisa tercipta lewat kemampuan bahasa anak dengan uraian terhadap warna. Sebaliknya anak bisa mengelompokkan maksudnya anak sanggup mengumpulkan sesuatu tipe warna jadi satu, keahlian tersebut bisa tercipta lewat kemampuan bahasa anak dengan uraian terhadap warna. Keahlian anak dalam perihal menunjuk, menyebut, serta mengelompokkan warna ini selaku dasar anak umur dini buat membangun keahlian kognitif logika. Selaku mana komentar (Rasyid, 2009) kalau menyebut, mengklasifikasikan, membedakan, serta menghitung warna ialah keahlian kognitif- logika anak yang digunakan selaku dasar melaksanakan asimilasi, menyesuaikan diri, serta akomodasi terhadap area serta suasana baru. dimana keahlian tersebut membentuk skema baru, sehingga anak mempunyai keahlian kegiatan memproses data.

Media pembelajaran yang menarik bagi anak dapat membuat anak lebih senang untuk belajar. Melalui metode pemberian tugas dapat membuat anak menjadi konsentrasi dalam menyelesaikan suatu pekerjaannya. Motivasi dan pujian yang telah diberikan juga dapat membuat anak lebih percaya diri, serta dapat membuat anak lebih mandiri.

\section{SIMPULAN}

Adapun kesimpulan dari penelitian adalah warna-warna yang sangat menarik dapat meningkatkan daya kognitif anak, yaitu berpikir dan bereksperimen, rasa ingin tahu muncul dengan sendirinya, apabila anak melihat warna yang menarik. Untuk meningkatkan pengenalan warna pada anak Taman Kanak-kanak maka dapat dilakukan dengan kegiatan-kegiatan yang menarik. 
Kemampuan mengenal warna dinilai bagi 3 (tiga) keahlian ialah menunjuk, menyebut, serta mengelompokkan.

Manfaat yang bisa diperoleh anak dari kegiatan- kegiatan pengenalan warna, antara lain anak bisa berekspresi, komunikasi, bermain, pengembangan bakat seni, pengembangan keahlian berpikir, perolehan estetika, pengenalan macam- macam warna, melatih motorik halus anak, anggapan, serta kreatifitas besar.

Dari hasil penerapan pemberian tugas pada anak kelompok B Taman Kanak-kanak Negeri Pembina Sungai Raya dalam keahlian memahami warna ada kenaikan. Dengan hasil tugas yang diberikan diperoleh $21 \%$ pada dikala pratindakan, $31,11 \%$ pada dikala siklus I, serta $82,22 \%$ pada dikala siklus II.

Bersumber pada hasil riset yang sudah dicoba, hingga dianjurkan guru sebaiknya lebih kreatif dalam memilah media serta tata cara yang pas dalam pendidikan. Media yang bisa digunakan dalam memahami warna tidak hanya kertas origami merupakan kancing pakaian, tanaman( bunga, tumbuhan, daun, rumput), serta balon. Setelah itu guru pula wajib lebih aktif serta lebih kreatif memakai model ataupun tata cara dalam pendidikan sehingga anak menjadi senang dan semnagat saat melaksanakan proses pembelajaran berlangsung. Dengan demikian akan menjadikan pembelajaran lebih bermakna. Selain itu, diharapkan kepada guru mencari solusi bersama-sama teman sejawat agar pembelajaran lebih baik lagi. Kemudian guru hendaknya mengikuti seminarseminar untuk meningkatkan kreatifitas dalam pengembangan media belajar anak.

\section{REFERENSI}

Abdullah, I.H., \& Suratno, J. (2015). Pengaruh Pendekatan Pembelajaran Berbasis Masalah Terhadap
Kemampuan Komunikasi Matematis Siswa. Journal Pengajaran MIPA, 20(2), 1.

Acep, Y. (2010). Menyusun Penelitian Tindakan Kelas. Yogyakarta: Familia.

Nugraha, Ali. (2008). Pengembangan Pembelajaran Sains pada Anak Usia Dini. Dirjen Dikti Depdiknas: Jakarta.

Depdiknas. (2007). Pedoman Pembelajaran Permainan Berhitung Permulaan di Taman Kanak-kanak. Jakarta: Depdiknas.

Arikunto, S. (2006). Dasar-Dasar Evaluasi Pendidikan. Bumi Aksara.

Baniyah. (2009). Menumbuhkan Kemandirian dan Kreativitas Pola Pikir Anak Usia Pra Sekolah. Yogyakarta: SMAN 7 Yogyakarta.

Burhan, B. (2006). Metodologi Penelitian

Kuantitatif. Jakarta: Kencana Prenada Media Group.

Porter, De B., \& Hemacki, M. (2000). Quantum Learning. Bandung: Ka'ifa.

Depdiknas. (2009). Permendiknas No 58 Tahun 2009 Tentang Standar pendidikan Anak Usia Dini. Jakarta: Departemen pendidikan Nasional, Direktorat Jenderal Pendidikan, Direktorat Pendidikan Tenaga Kependidikan dan Ketenagaan Perguruan Tinggi.

Desmita. (2009). Psikologi Perkembangan Peserta Didik: Panduan bagi Orang Tua dan Guru dalam Memahami Psikologi Anak Usia SD,SMP,dan SMA. Bandung: Rosda.

Mutiah, Diana . (2010). Psikologi

Bermain Anak Usia Dini. Jakarta: Prenda Media Group.

Rasyid, Harun.. (2009). Asesmen Perkembangan Anak Usia Dini. Yogyakarta: Penerbit Multi Pressindo.

Haryono. (2007). Belajar dan 
mengembangkan kreativitas. Sudono, Anggani. (2000). Sumber Jakarta: Rineka Cipta.

Montolalu. (2005). Bermain dan Permainan Anak. Jakarta: Universitas Terbuka.

Musfiroh. (2008). Pengembangan Kecerdasan Majemuk. Jakarta: Universitas Terbuka.

Soewignjo, S. (2013). Seni Mengatur Komposisi Warna Digital. Yogyakarta: Taka Publisher.

Rosalina \& Nurhenti. (2019). Meningkatkan Kemampuan Kognitif Dalalam Mengenal Warna Melalui Metode Demonstrasi Dengan Media Lamu dan Baterai. Jurnal Lentera, 2(1), 1-9. file:///C:/Users/USER/AppData/L ocal/Temp/10595-

Article\%20Text-13803-1-1020150126.pdf Belajar dan Alat Permainan untuk Pendidikan Anak Usia Dini. Jakarta: PT Grasindo.

Sujiono, Y. . (2008). Metode Pengembangan Kognitif (p. 7). Jakarta: Penerbit Universitas Terbuka.

Susanto, A. (2012). Perkembangan Anak Usia Dini. Jakarta: Kencana Prenada Media Group.

Tedja, S., Mayke, S. (2001). Bermain, Mainan dan Permainan. Jakarta: PT Grasindo.

Winda, G., dkk. (2008). Metode Pengembangan Perilaku dan Kemampuan Dasar Anak Usia Dini. Jakarta: Penerbit Universitas Terbuka.

Yuliani, N, S. (2009). Konsep Dasar Pendidikan Anak Usia Dini. Universitas Terbuka: Jakarta. 